\title{
METHODS FOR ALLEVIATION AND REDUCTION OF THE EFFECTS OF GROWTH STRESSES IN Eucalyptus urophylla ${ }^{1}$
}

\author{
Juliana Cristina da Silva ${ }^{2 *}$, Ana Márcia Macedo Ladeira Carvalho ${ }^{3}$ and Bruno de Freitas Homem de Faria ${ }^{2}$ \\ ${ }^{1}$ Received on 09.05.2013 accepted for publication on 16.03.2017. \\ ${ }^{2}$ Universidade Federal de Viçosa, Programa de Pós-Graduação em Ciência Florestal, Viçosa, Minas Gerais. E-mail: \\ <jcsfloresta@yahoo.com.br>and<bruno.homemfaria@gmail.com>. \\ ${ }^{3}$ Universidade Federal de Viçosa, Departamento de Engenharia Florestal, Viçosa, Minas Gerais. E-mail: <ana.marcia@ufv.br>. \\ *Corresponding author.
}

\begin{abstract}
There are many species of the Eucalyptus genus presents high levels of the growth stress. These stresses are mechanical efforts generated during the tree growth to help maintaining the balance of the cup in response to environmental and silvicultural agents. The stresses are responsible for the cracks of tops and for the warp after unfolding. The objective of this study was to test five different methods to minimize the effects of growth stress on the production of Eucalyptus urophylla sawlogs. The boards produced were then evaluated and measured for cracking, arching, curvature and cupping. The treatment with herbicide presented the smallest medium indexes of cracking $(16.63 \mathrm{~cm})$ and of arching $\left(0.23 \mathrm{~mm} . \mathrm{m}^{-1}\right)$, while the medium curvature was smaller than observed in boards unfolded in 72 hours after the reduction of the trees $(0.88$ $\mathrm{mm} . \mathrm{m}^{-1}$ ). Unfolding after ten days of harvesting represented the less efficient technique in the cracking control, curvature and arching. The cupping was not observed during boards processing. The herbicide application was more efficient in the reduction of the effects of the growth tensions.
\end{abstract}

Keywords: Unfold of the wood; Defects in wood; Sawmill.

\section{MÉTODOS DE ALÍVIO E REDUÇÃO DOS EFEITOS DE TENSÃO DE CRESCIMENTO EM Eucalyptus urophylla}

RESUMO - São muitas as espécies do gênero Eucalyptus que apresentam altos níveis de tensões de crescimento. Essas tensões são esforços mecânicos gerados durante o crescimento da árvore que ajudam a manter o equilíbrio da copa, em resposta a agentes ambientais e silviculturais. As tensões de crescimento são responsáveis pelas rachaduras de topo e pelos empenamentos após o desdobro. O objetivo deste trabalho foi testar cinco técnicas para a redução dos efeitos da tensão de crescimento na produção de toras de Eucalyptus urophylla. Após a obtenção e desdobro das toras foram avaliados as rachaduras, o arqueamento, o encurvamento e o encanoamento. $O$ tratamento com herbicida apresentou os menores índices médios de rachadura $(16,63 \mathrm{~cm})$ e de arqueamento $\left(0,23 \mathrm{~mm} . \mathrm{m}^{-1}\right)$, enquanto o encurvamento médio foi menor observado em tábuas desdobradas em 72 horas após o abatimento das árvores $\left(0,88 \mathrm{~mm} . \mathrm{m}^{-1}\right)$. O desdobro após dez dias ao abate representou a técnica menos eficiente no controle de rachadura, encurvamento e arqueamento. O encanoamento não foi observado durante o processamento das tábuas. A aplicação de herbicida foi a técnica mais eficiente na redução do efeito das tensões de crescimento.

Palavras-chave: desdobro da madeira, defeitos na madeira, serraria. 


\section{INTRODUCTION}

The growing acceptance by the market of wood, cut from species of the genus Eucalyptus has been largely caused by better understanding, by the spread of the species, greater availability, as well as growing social pressure to reduce the use of native woods (Lima and Garcia, 2008). Additionally, the adaptability to diverse soil and climate conditions, rapid growth and versatility of use of the wood for industrial purposes (Santos et al., 2004), also allow satisfaction of regular industrial supply.

Due to its physico-mechanical and organoleptic properties, eucalyptus wood is seen to be an alternative to substitute regularnative species (Severo, 1998), being able to significantly contribute to supplying internal and external demands, showing itself to be adequate for diverse ends.

Even given the evidence that the production and consumption of timber cut from Eucalyptus is showing significant growth, in the milling community, there is still strong resistance to the use of wood in operations of sawing and drying.

Similarly, considering the use of Eucalyptus wood as a possible alternative for raw material for the production of plywood and in the lamination industry, for carpentry and the furniture industry generally largely provokes immediate negative reactions. These reactions are justified by setbacks during processing of the wood, due to the appearance of innumerable defects, which lead to considerable losses of raw material, and consequently, economic losses.

Some problems are confronted with the greater use of eucalyptus, particularly as timber cut for diverse purposes. Amongst these are growth stresses, elevated retratibility and collapse during drying (Ponce, 1995; Oliveira, 1997; Rocha, 2000). These forces originate in the cambial region during the maturation of the cells. Also during maturation, longitudinal contractions can occur and, at the same time, transversal expansions (Lima et al., 2000).

The manifestations of the release of growing stresses and drying defects lead to a significant loss of timber, since they show themselves in the form of cracks, warps and torsions.

It is possible to affirm that growing stresses are the main agent responsible for poor outcomes while processing eucalyptus wood, due to the reduction in the dimensions of the pieces. These restrictions on the use of this material are more prominent in younger rather than adult forests, as a consequence of diverse intrinsic factors of the wood (Nicholson, 1973).

Some studies developed in recent years, seek to understand, quantify and create control methods for these cracks and warping, provoked by growth stresses, trying to correlate them with other characteristics of the wood (Garcia, 1992; Souza, 2002; Trugilho et al., 2006). Therefore, reduction of these defects has a more significant effect on the quality and the outcome of the final product, leading to an wider acceptance of the wood on the market (Rodrigues, 2007).

Many techniques were developed and continue to be improved to minimize the effects of growth stresses in Eucalypts. Amongst these, the application of top sealing (Skolmen, 1967; Aguiar, 1986; Matos et al., 2003), log storage with water sprinkling (Nicholson, 1973; Aguiar, 1986), vaporization (Severo and Tomaselli, 2000; Calonego and Severo, 2005), ringing (Severo and Tomaselli, 2000; Matos et al., 2003; Calonego and Severo, 2005) and the application of herbicide (Matos et al., 2003; Rocha and Trugilho, 2006; Cademartori et al., 2015).

The use of new genetic materials for genetic improvement programs can also minimize the negative effects caused by high levels of growth stresses in the production of cut wood (Santos et al., 2004).

The clear success of the alternative uses of wood from species of Eucalyptus, beyond depending on a large scale of development of technology at an industrial level, is closely linked to adequate management, to the correct selection of species, to genetic improvement and the use of techniques that avoid the appearance of defects prior to the phase of the utilization of the timber.

Therefore, the objective of this study was to determine the most appropriate technique to reduce the effects of growth stresses in Eucalyptus urophylla and in this manner, allow a greater output of cut timber, seeking to reduce resistance from the furniture sector to the use of this raw material, as well as to reduce the quantity of refuse wood due to cracking.

\section{MATERIALAND METHODS}

The species used in this study was the Eucalyptus urophylla obtained from commercial plantations with 13 years of age, from the company Capivari Agropecuária 
LTDA, located in the municipality of Itamarandiba. The experimental area is situated in the Alto Vale do Jequitinhonha, in the northeast of Minas Gerais, with approximate coordinates of Latitude: $-17^{\circ} 51^{\prime} 26^{\prime \prime}$ and Longitude: $42^{\circ} 51^{\prime} 32^{\prime \prime}$. The climate of the region is of the Cwa type (tropical altitude) according to the Köppen classification, with average precipitation of $1.160 \mathrm{~mm}$ and an average annual temperature of $20^{\circ} \mathrm{C}$ (Pulrolnik et al., 2009).

Logs of a length of 5.6 meters for subsequent processing were obtained from the Serreria Meira, located in the same municipality. To obtain this material, 50 trees were selected with good trunk formation and diameter at the height of the chest around $22 \mathrm{~cm}$. On the trunks obtained, five treatments were applied, with 10 trees for each treatment. The procedure utilized followed the methodology adopted by Rocha (2000) and Matos et al. (2003).

The first treatment consisted in, prior to felling, making the girdling with the chainsaw on the trees, seeking to partially release growth stresses. The process consisted in carrying out the girdling at a depth of a third of the ray of the tree, at a distance of 20 centimeters above the line of the cut. After felling the trees, another ring was made on the upper end of the log. In this manner, the logs had a length of $5.6 \mathrm{~m}$ and $20 \mathrm{~cm}$ more after the rings, totaling a length of 6.0 meters. After girdling, the logs remained in the field for 12 days, and subsequently, were sent to be cut.

To promote the physiological paralysation of the trees, $1 \mathrm{~mL}$ of systemic herbicide "Round up, was applied at a height correspondent to the DAP of each tree, making up the second treatment. To this end, a hole was made with a nail at an angle of $45^{\circ}$ and the injection of the liquid was made with a veterinary syringe. The trees remained in the field for twenty-nine days, standing up, under the effect of the herbicide, leading to their death, which caused the interruption of metabolic activity, and consequently, reduced moisture levels. After this period, the trees were felled and traced to obtain the logs, which were then taken for sawing.

In the third treatment, the trees were felled and traced into logs of 5.6 meters of length, on which waterproofing, "Neutrol”, from Vedacit $\AA$, was applied aiming to slow the rate of water loss from the ends of the logs. They were left in the field for thirty days, before being taken to for sawing.
The fourth treatment consisted in felling the tree and immediately carrying out the tracing. The logs obtained remained in the field for ten days before being taken for sawing.

For the fifth treatment, the trees were felled and immediately traced. The logs obtained waited 72 hours from the moment of being traced until being sawed in the sawmill.

The ten logs obtained for each one of the five treatments were transported to the sawmill, being traced into two logs of a length of $2.8 \mathrm{~m}$ and, those with ringing had the rings removed. In this manner, the $20 \operatorname{logs}$ for each treatment were processed.

During the sawing of the logs, a multiple circular saw with two blades for the main sawing, multiple circular saw and a multiple circular saw with two blades for the resawing were used. Four simultaneous cuts were made using the main saw, resulting in two outer boards, two boards with a thickness of $38 \mathrm{~mm}$ and a central semi-block with a thickness of $160 \mathrm{~mm}$. The boards obtained on the main saw were sent to the circular saw and recut to a standard width. The semi-block was sent to the re-sawer and cut into boards with a $27 \mathrm{~mm}$ thickness.

After the sawing of the logs, 100 boards were randomly selected from each treatment for the assessment of indices of arching, curvature and cupping as presented in Figure 1.

The intensity of the cracks in the ends was obtained via the sum of all the cracks in the two extremities of the logs (Figure 1.A), as realized in the study by Borges and Quirino (2005) for Eucalyptus grandis. For this determination, the following formula was used:

$$
\mathrm{ICL}=\Sigma(\mathrm{I} 1+\mathrm{I} 2)
$$

In which:

$\mathrm{ICL}=$ indices of cracking of logs; $\mathrm{I} 1=$ length of all cracks in the extremities $1(\mathrm{~cm})$ and $\mathrm{I} 2=$ length of all the extremities $2(\mathrm{~cm})$.

The measurements of arching were obtained, according to Rocha (2000), as seen in figure 1, using the formula:

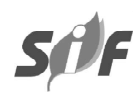

Revista Árvore. 2017;41(4):e410403 
Fonte: Rocha (2000).

Source: Rocha (2000).

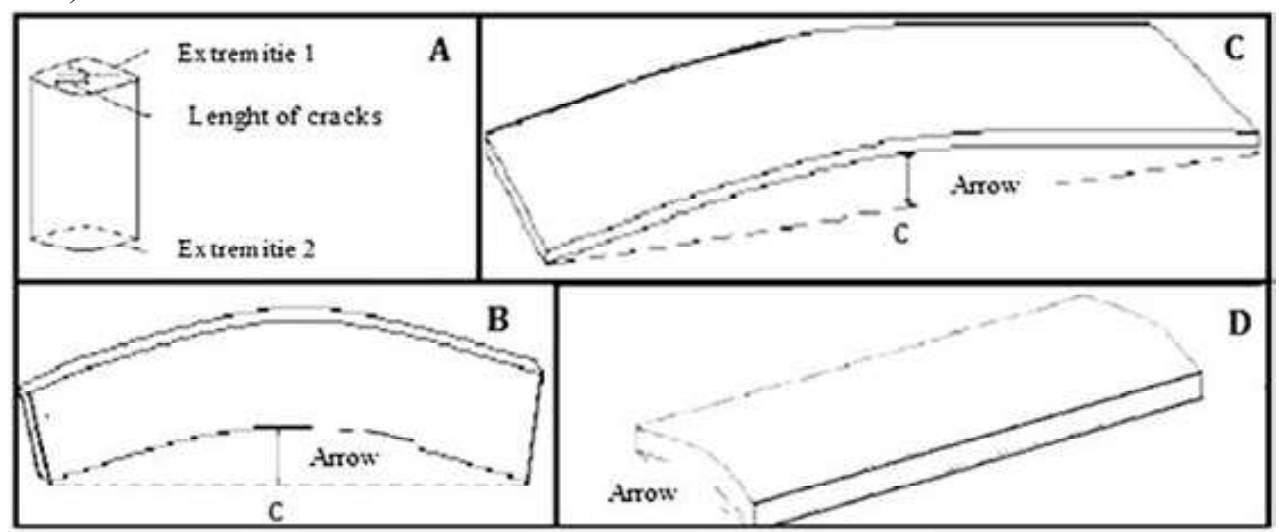

Figure 1 - Analysis of deformation: A) Details of the top cracks in the logs; B) Detail arching of boards; C) Detail curvature of boards; D) Detail cupping of the boards.

Figura 1 - Análise das deformações: A) Detalhes das rachaduras de topo nas toras; B) Detalhe do arqueamento das tábuas; C) Detalhe do encurvamento das tábuas; D) Detalhe do encanoamento das tábuas.

In which: $A=\operatorname{arching}\left(\mathrm{mm} \cdot \mathrm{m}^{-1}\right) ;$ arching $(\mathrm{mm})$ and $\mathrm{c}=$ length of the piece $(\mathrm{m})$.

The curvature was measured, as seen in figure 1.C, using the formula:

In which: En $=$ curvature $(\mathrm{mm} / \mathrm{m}) ;$ curvature $(\mathrm{mm})$ and $\mathrm{c}=$ length of the piece $(\mathrm{m})$.

The cupping was measured, as seen in figure 1.D, and its values were presented as its maximum arrow in millimeters.

The statistical analysis was realized using the Statistic 12.0 program. Finding that the data followed normality and homoscedasticity, the Tukey test, at $5 \%$ probability was carried out, and in the case of not achieving normality and homoscedasticity, the transformation of the data as Campos (2000) reported was realized.

\section{RESULTS}

When submitting the data referent to each treatment to tests for normality and homoscedasticity, it was found that all of them followed normality, however only the data referent to curvature was found to be homoscedastic. Therefore, the direct logarithmic transformation of the data $(\log x+1)$, for the cracking and arching was performed, taking into account the assumptions of the analysis of variance (ANOVA).
In Table 1, the results for curvature, arching and cracking are presented for the five treatments tested, taking the twenty logs processed of Eucalyptus urophylla according to each treatment applied.

In Table 2, the results for average curvature were presented, followed by the transformed results for cracking and arching. The results of the Tukey test were also presented.

In Figure 2, maximum and minimum values obtained for each deformation evaluated in this study are presented.

\section{DISCUSSION}

In Table 1, we observe that the sum of the logarithmic data does not have the same value as the sum of their algorithms. According to Campos (2000), this behavior is expected, since the average of the logarithms does not correspond to the average logarithm of its antilogarithms. In truth, the antilogarithm of the average of the logarithm corresponds to the geometrical average

Table 1 -Average results of the cracking, arching and curvature. Tabela 1 -Resultados médios de rachaduras, arqueamento

\begin{tabular}{lccc}
\multicolumn{4}{c}{ e encurvamento. } \\
\hline Treatment & $\begin{array}{c}\text { Curvature } \\
\left(\mathrm{mm} \cdot \mathrm{m}^{-1}\right)\end{array}$ & $\begin{array}{c}\text { Cracking } \\
(\mathrm{cm})\end{array}$ & $\begin{array}{c}\text { Arching } \\
\left(\mathrm{mm}^{-1}\right)\end{array}$ \\
\hline Girdling & 1,60 & 26,73 & 5,61 \\
Herbicide & 2,63 & 16,63 & 0,23 \\
Sealant & 2,36 & 40,22 & 0,89 \\
Logs 72 h & 0,88 & 19,68 & 4,83 \\
Logs 10 days & 2,46 & 27,57 & 4,98 \\
\hline
\end{tabular}


Table 2 - Result of average curvature, followed by the results transformed cracking and arching.

Tabela 2 - Resultados de encurvamento médio, seguido pelos resultados transformados de rachaduras e arqueamento.

\begin{tabular}{lccr}
\hline Treatment & $\begin{array}{c}\text { Curvature } \\
\left(\mathrm{mm} \cdot \mathrm{m}^{-1}\right)\end{array}$ & $\begin{array}{c}\text { Cracking* } \\
(\mathrm{cm})\end{array}$ & $\begin{array}{r}\text { Arching* } \\
\left(\mathrm{mm} \cdot \mathrm{m}^{-1}\right)\end{array}$ \\
\hline Girdling & $1,60^{\mathrm{ab}}$ & $2,39^{\mathrm{ab}}$ & $1,73^{\mathrm{c}}$ \\
Herbicide & $2,63^{\mathrm{b}}$ & $2,21^{\mathrm{a}}$ & $0,35^{\mathrm{a}}$ \\
Sealant & $2,36^{\mathrm{ab}}$ & $2,60^{\mathrm{c}}$ & $0,95^{\mathrm{b}}$ \\
Logs $72 \mathrm{~h}$ & $0,88^{\mathrm{a}}$ & $2,29^{\mathrm{ab}}$ & $1,68^{\mathrm{c}}$ \\
Logs 10 days & $2,46^{\mathrm{b}}$ & $2,44^{\mathrm{bc}}$ & $1,69^{\mathrm{c}}$ \\
\hline
\end{tabular}

Averages, in the same column, followed by less than one common letter, are not distinguished by the Tukey test at $5 \%$ probability. * Represents transformed data.

Médias, na mesma coluna, seguidas por pelo menos uma mesma letra não se diferem pelo teste Tukey a $5 \%$ de probabilidade.

*Representa dados transformados.

of the original data, and not to its arithmetical average (Campos, 2000).

In terms of average curvature, the herbicide treatment showed the highest value, $2.63 \mathrm{~mm} . \mathrm{m}^{-1}$, with only the logs processed 72 hours after the tree was felled being statistically different, showing a lower average value $\left(0.88 \mathrm{~mm} \cdot \mathrm{m}^{-1}\right)$. These values obtained are below those found by Matos et al. (2003), who for Eucalyptus dunnii found the highest average value of $4.99 \mathrm{~mm} \cdot \mathrm{m}^{-1}$ for sawing in 72 hours and a lower average value of $3 \mathrm{~mm} \cdot \mathrm{m}^{-1}$ for the herbicide treatment.

The maximum curvature (Figure 2) was observed in boards obtained from logs with 10 days in the field $\left(4.88 \mathrm{~mm} . \mathrm{m}^{-1}\right)$ and the lowest value in non-sawed boards 72 hours after harvesting $\left(0.017 \mathrm{~mm} \cdot \mathrm{m}^{-1}\right)$.

Simpson (1991) affirms that curvature is present due to the influence of longitudinal contraction of the juvenile wood present near the medulla of the tree as well as the compression and contraction of wood, which occurs in trees with an inclined and overlapping grain.

In terms of cracking, we can observe, in Table 1, that the herbicide treatments $(16.6 \mathrm{~cm})$, followed by un-sawed wood in 72 hours $(19.6 \mathrm{~cm})$ and by girdling $(26.73 \mathrm{~cm})$ showed the lowest averages, with these being statistically equal (Table 2). This can be explained given that by applying the herbicide, this provokes the death of the tree, making it lose its moisture, which reduces the effect of drying stresses. Another explanation is that by making the hole in the tree to apply the herbicide, there was a partial liberation of the stress, which resulted in small cracks in the sawed pieces.
Comparing the results obtained with the literature, we can see that Del Menezzi et al. (2001), who sawed two Eucalyptus grandis logs after treatment by herbicide, obtained much lower cracking indices, with values of 4.39 and $6.18 \mathrm{~cm}$ in the first and in the second respectively. Matos et al. (2003) also found lower values in Eucalyptus dunnii $(14.7 \mathrm{~cm})$ after herbicide treatment, showing that this technique was more efficient at reducing cracks in the ends than other techniques. Cademartori (2015) affirms that the herbicide treatment acts indirectly to minimize the indices of cracking after drying, with the authors observing in this study that the increase in the indices of end cracks was related to drying stresses released during the operation in the open air.

The highest value for indices of cracking was found in logs submitted to the treatment of end sealant (106.4 $\mathrm{cm})$, while the lowest was observed in logs processed 72 hours after harvesting $(5.8 \mathrm{~cm})$.

The treatment with application of end sealant showed the highest average value for indices of cracking of $\operatorname{logs}(40.2 \mathrm{~cm})$, but it did not differ statistically from the logs processed after 10 days in the field. In the research by Matos et al. (2003), the value of the indices of cracking of logs was $33.74 \mathrm{~cm}$ in Eucalyptus dunnii, therefore the authors concluded that this technique was less efficient than the others.

The technique of applying sealant consists in reducing the speed of capillary water loss, seeking lower moisture rates in the interior of the logs. This promotes a reduction in the occurrence of cracking from drying. In this manner, as this was the treatment, which presented the highest indices of cracking, we can say that the growth stresses were more evident than initial water loss in the appearance of cracking in the logs.

For arching, the treatment with herbicides was seen to be the most efficient, with $70 \%$ of the boards showing indices of arching equal to $0 \mathrm{~cm}$ (zero). This treatment presented the lowest average arching $\left(0.23 \mathrm{~mm} . \mathrm{m}^{-1}\right)$, followed by the sealant $(0.89 \mathrm{~cm})$. The girdling treatment presented the highest indices of arching $\left(1.05 \mathrm{~mm} . \mathrm{m}^{-1}\right)$, while the herbicide treatment presented the lowest indices together with the end sealant $\left(0.00 \mathrm{~mm} \cdot \mathrm{m}^{-1}\right)$.

As can be seen in Table 2, the average values for arching of the logs submitted to girdling were not statistically different from the average values of logs processed 72 hours after harvesting after ten days in the field. Only the herbicide treatment presented 


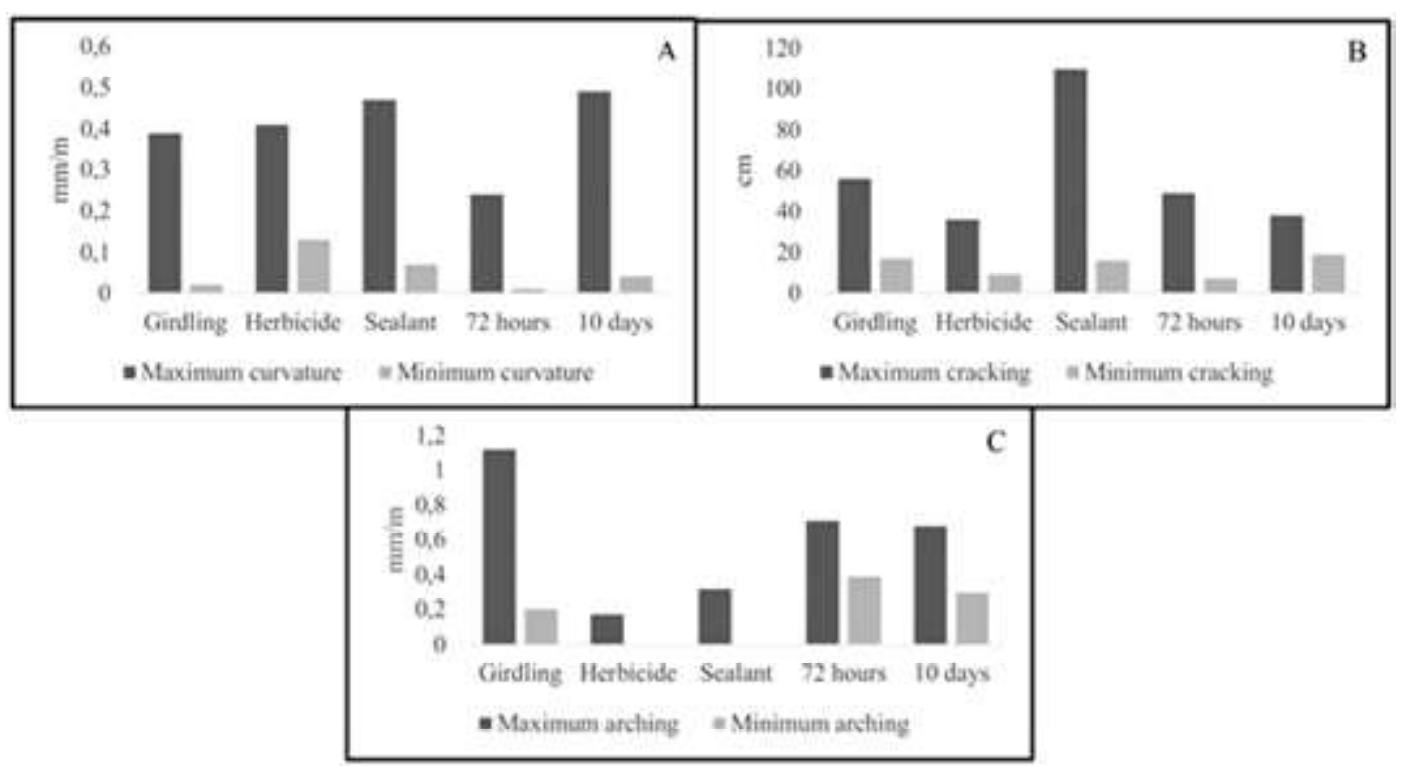

Figure 2 - Maximum and minimum deformation in boards and logs: A) Curvature of boards; B) Cracking; C) Arching of boards.

Figura 2 - Deformações máximas e minimas em tábuas e toras de Eucalyptus urophylla. A) Encurvamento em tábuas; B) Rachadura em toras; C) Arqueamento em tábuas.

a lower average to the lowest average encountered by Matos et al. (2003) which was $0.38 \mathrm{~mm} . \mathrm{m}^{-1}$ in the girdling treatment of the Eucalyptus dunni. By contrast, Rocha and Tomaselli (2002) observed average arching in the wood sawed (tangential cutting) of Eucalyptus grandis of $0.21 \mathrm{~mm} . \mathrm{m}^{-1}$ (logs with a diameter between 25 and $30 \mathrm{~cm}$ ) after the utilization of ringing and vaporization techniques. Therefore, Ferreira et al. (2004) observed average arching of $0.61 \mathrm{~mm} . \mathrm{m}^{-1}$ in 10 hybrid clones of Eucalyptus.

Generally, the technique of sawing trees 10 days after felling was seen to be a less efficient technique for the reduction of the effects of growth stresses, despite this being a more common technique in the routine of the sawmills. The longer the time that the log remained in the open air, without being sawed, the worse the consequences from growth stress (Soriano and Gonçalves, 2011). Given this, the logs processed up to 72 hours after harvesting showed lower values for deformations when compared with the logs processed after 10 days. The ideal would be to cut down the tree, transport it to the sawmill and saw it there as quickly as possible. According to Barnacle (1971) and Malan (1984), drying stresses interact with growth stresses to produce cracking of the ends. We can obtain improvements if it were possible to transport the log in greater lengths and if the sectioning takes place only when the piece is to be sawed.

According to Soriano and Gonçalves (2011), if the $\log$ s had to be stored for a short period of time, the best thing is to do this employing the ringing technique, with a reduction of $50 \%$ of growth stress being observed in their study when employing the ringing technique in Eucalyptus camaldulensis. These same authors cite various difficulties with utilizing this technique such as risk of fire, use of drills, logistical difficulties and with the harvesting operations and the reuse of land.

In the present study herbicide use pointed toward more efficient techniques for the reduction of defects resultant from growth stress in $\operatorname{logs}$ and boards. Cademartori (2015) considers that herbicide use becomes more interesting for the reduction of the effect of growth stresses in timber, given that the time for the application of the product and technological investment are less, when compared with the other techniques, such as girdling and vaporization, respectively. By contrast, there is the disadvantage of possible economic and temporal unviability for the use of the product over 
the large reforestation areas used by industries in the timber sector.

In evaluated boards, warping was not seen. However, in a subsequent evaluation, with the boards already in their dry state, this effect was evident, since it is associated with the contraction of the volume that the timber suffers during drying.

\section{CONCLUSIONS}

The treatments realized show different responses between the processed logs and boards. The utilization of techniques here evaluated is important due to the reduction of effects resultant from growth stresses, allowing a reduction in the quantity of refuse $\log s$, better returns on cut timber and aggregated value to the pieces.

The method to obtain the logs through the death of the tree with herbicide application is the most efficient to reduce the effect of growth stress, presenting cracking and arching at a lower level.

Herbicide treatment provides logs with lower indices of cracking, while the technique of applying end sealant results in higher values for this parameter.

Curvature is a defect observed at lower levels in boards obtained from logs processed 72 hours after being felled.

Sawing ten days after being cut down, evaluating all the defects together, was seen to be the least efficient technique to reduce the effects of growth tensions.

Warping was not observed in any treatment with boards still in their green state.

\section{REFERENCES}

Aguiar OJR. Método para controle das rachaduras de topo em toras de Eucalyptus grandis Hill. Ex Maiden, visando a produção de lâminas por desenrolamento [dissertação]. Piracicaba: Escola Superior de Agricultura Luiz de Queiroz; 1986.

Barnacle JE. Notes on felling damage and its interaction with tree growth stresses. In: Proceedings Symposium on the effect of Tree Injuries, Felling and Growth Stresses on Log Quality and Timber Utilization. Gainsville: IUFRO; 1971.
Borges LM, Quirino WF. Redução do efeito das tensões de crescimento no Eucalyptus grandis pelo tratamento térmico. In: Anais do $3^{\circ}$ Seminário de Produtos Sólidos de Madeira de Eucalipto SIF [CD-ROM]. Vitória: SESI; 2005.

Cademartori PHG, Gatto DA, Stangerlin DM, Mastella T, Vargas JF, Santini EJ. Uso de herbicida na redução das tensões de crescimento na madeira serrada de Eucalyptus grandis. Ciência Florestal. 2015;25:801-8.

Calonego FW, Severo ETD. Efeito da vaporização de toras na redução dos defeitos associados a tensões de crescimento de Eucalyptus grandis. Ciência Florestal. 2005;15:431-40.

Campos GM. Estatística prática para docentes e pós-graduandos. 2000. [acesso em: 19 set. 2015] Disponível em: http://www.forp.usp.br/ restauradora/gmc/gmc_livro/ gmc_livro_cap13.html..

Del Menezzi CHS, Nahuz MAR, Souza MR. Aspectos tecnológicos da produção de madeira serrada de Eucalyptus cloeziana F. Muell. Brasil Florestal. 2001;70:75-82.

Ferreira S, Lima JT, Rosado SCS, Trugilho PF. Influência de métodos de desdobro tangenciais no rendimento e na qualidade da madeira de clones de Eucalyptus spp. Cerne. 2004;10:10-21.

Garcia JN. Estados de tensão em árvores e de deformação em peças de madeira serrada [tese]. São Paulo: Universidade de São Paulo; 1992.

Lima IL, Garcia JN. Influência do desbaste e da fertilização nos índices de rachamento após desdobro e secagem em madeira serrada de Eucalyptus grandis Hill ex-Maiden. Revista do Instituto Florestal. 2008;20:175-84.

Lima IL, Garcia JN, Nogueira MCS. Influência do desbaste nas tensões de crescimento de Eucalyptus grandis Hill ex-Maidem. Scientia Forestalis. 2000;58:111-25.

Malan FS. Studies on the phenotypic variation in growth stress intensity and its association with tree and wood properties of South African grown Eucalyptus grandis (Hill ex maiden) [these] Stellembosh: University of Stellembosh; 1984. 
Matos JLM, Iwakiri S, Rocha MP, Paim RM, Andrade LO. Redução do efeito das tensões de crescimento em toras de Eucalyptus dunnii. Scientia Forestalis. 2003;64:128-35.

Nicholson JE. Growth stress differences in eucalypts. Forest Science. 1973;19:169-74.

Oliveira JTS. Caracterização da madeira de eucalipto para a construção civil [tese]. São Paulo: Escola Politécnica da Universidade de São Paulo; 1997.

Ponce RH. Madeira serrada de eucalipto: desafios e perspectivas. In: Anais do Seminário Internacional de Utilização da Madeira de eucalipto para Serraria. Piracicaba: IPEF/IPT/ IUFRO/LCF-ESALQ-USP; 1995. p.50-8.

Pulrolnik K, Barros NF, Silva IR, Novais RF, Brandani CB. Estoques de carbono e nitrogênio em frações lábeis e estáveis da matéria orgânica de solos sob eucalipto, pastagem e cerrado no Vale do Jequitinhonha - MG. Revista Brasileira de Ciência do Solo. 2009;33:1125-36.

Rocha MP. Eucalyptus grandis Hill ex Maiden e Eucalyptus dunnii Maiden como fontes de matériaprima para serrarias [tese]. Curitiba: Universidade Federal do Paraná; 2000.

Rocha MP, Tomaselli I. Efeito do modelo de desdobro na qualidade da madeira serrada de Eucalyptus grandis e Eucalyptus dunnii. Cerne. 2002;8:70-83.

Rocha MP, Trugilho PF. Qualidade da madeira serrada de Eucalyptus dunnii em função do método de desdobro e condição de umidade. Cerne. 2006;12:314-21.

Rodrigues EAC. Estimação de parâmetros genéticos, fenotípicos e ambientais para a qualidade da madeira de Eucalyptus em árvores vivas [tese]. Lavras: Universidade Federal de Lavras; 2007.

Santos PET, Geraldi IO, Garcia JN. Estimates of genetic parameters of wood traits for sawn timber production in Eucalyptus grandis. Genetics and Molecular Biology. 2004;27:567-73.

Severo ETD. Estudo sobre o efeito da vaporização nas propriedades e comportamento de secagem da madeira de Eucaliptus dunnii Maiden [tese]. Curitiba: Universidade Federal do Paraná; 1998.

Severo ETD, Tomaselli I. Efeito da vaporização no alívio das tensões de crescimento em toras de duas procedências de Eucalyptus dunnii. Scientia Agraria. 2000;1:29-32.

Simpson WT. Dry kiln operator's manual: Drying defects. Madison: U.S. Department of Agriculture; 1991.

Skolmen RG. Heating logs to relieve growth stresses. Forest Products Journal. 1967;17:41-2.

Soriano J, Gonçalves R. Tensões de crescimento em coníferas e dicotiledôneas. 2011. [acesso em: 20 de maio de 2016]. Disponível em: http:// estruturasdemadeira.blogspot.com.br/2011/01/ tensoes-de-crescimento-em-coniferas-e.html.

Souza MAM. Deformação Residual Longitudinal (DRL) causada pelas tensões de crescimento em clones de híbridos de Eucalyptus [dissertação]. Lavras: Universidade Federal de Lavras; 2002.

Trugilho PF, Lima JT, Pádua FA, Soragi LC, Andrade CR. Deformação Residual Longitudinal (DRL) e tangencial (DRT) em seis clones de Eucalyptus spp. Cerne. 2006;12:279-86.

\section{ERRATA}

No artigo "METHODS FOR ALLEVIATION AND REDUCTION OF THE EFFECTS OF GROWTH STRESSES IN Eucalyptus urophylla”, publicado no número 4, volume 41, da Revista Árvore, onde se lê:

http://dx .doi.org/10.1590/1806-90882017000200003

Leia-se:

http://dx .doi.org/10.1590/1806-90882017000400003 